\title{
COMPARATIVE ACTIVITY OF TOTAL POLYPHENOLS AND ANTIOXIDANT COMPOUNDS FROM UNCARIA TOMENTOSA ENHANCED WITH CITRIC ACID
}

\author{
ATIVIDADE COMPARATIVA DE POLIFENÓIS TOTAIS E COMPOSTOS ANTIO- \\ XIDANTES DA UNCARIA TOMENTOSA POTENCIADA COM ÁCIDO CÍTRICO \&
}

ACTIVIDAD COMPARATIVA DE POLIFENOLES TOTALES Y COMPUESTOS ANTIOXIDANTES DE UNCARIA TOMENTOSA POTENCIALIZADA CON ÁCIDO CÍTRICO \&

Recebido em: 29/10/2020 - Aprovado em: 11/12/2020 - Publicado em: 20/04/2021

http://dx.doi.org/10.18011/bioeng2021v15n1p69-89

Cesar Augusto Roque Borda1 (cesar.roque@unesp.br)

Camila Katerine Aranda Medina² (ckam4000@gmail.com)

Raiza Felismino Silveira' (raiza.silveira@unesp.br)

Priscilla Ayleen Bustos Mac-Lean ${ }^{3}$ (priscilla.mac-lean@unesp.br)

Angela Vacaro de Souza ${ }^{3}$ (angela.souza@unesp.br)

Fernando Ferrari Putti ${ }^{3}$ (fernando.putti@unesp.br)

Eduardo Festozo Vicente ${ }^{3}$ (eduardo.vicente@unesp.br)

1 São Paulo State University (UNESP), School of Agricultural and Veterinarian Sciences, Jaboticabal, São

Paulo, Brazil.

2 Universidad Católica de Santa María, Facultad de Ciencias Farmacéuticas Bioquímicas y Biotecnológicas, Arequipa, Perú.

${ }^{3}$ São Paulo State University (UNESP), School of Sciences and Engineering, Tupã, São Paulo Brazil.

\section{ABSTRACT}

Uncaria tomentosa, a climbing vine notable for containing high concentrations of oxindole alkaloids and phenolic compounds, is commonly used in traditional medicine as an anti-inflammatory and antioxidant agent. Also, the citric acid is a food additive widely used for conservation, due to its low cost. In this way, this study aims to evaluate the content of phenolic compounds from Uncaria tomentosa and investigate its antioxidant activity when citric acid, at different concentrations, is added to the extract. For this purpose, a gradient of citric acid concentrations was established, and the antioxidant profile from a aqueous extracts of the plant leaves and bark was analyzed by Folin-Ciocalteu essay; inhibition of the free radical of 2,2-diphenyl-1-picrylhydrazyl (DPPH); ferric reducing antioxidant power (FRAP), and scavenging capacity of cationic free radicals of 2,2'azino-bis(3-ethylbenzothiazoline-6-sulfonic acid) (ABTS). The results showed a synergistic effect between citric acid and antioxidant compounds from Uncaria tomentosa, presenting highly statistical significance, the synergistic effect was more efficient in the bark than in the leaves.

Keywords: ABTS. DPPH. Folin-Ciocalteu. FRAP. Synergistic Effect. 


\section{INTRODUCTION}

The oxidation of food products is one of the major causes of chemical degradation, due to the presence of free radicals that can cause rancidity, in which properties such as taste, smell, texture and color are modified (Suja et al., 2004; Antolovich et al., 2002). Studies based on natural antioxidants have been increased due to the low safety provided by common synthetic antioxidants. Alternatively, the effectiveness of phytochemicals and the fact that these compounds can positively affect the pathology of chronic diseases and the aging process have been emerging as promising natural antioxidants. In addition, consumers believe that natural products are safer than synthetical ones, and more acceptable as natural antioxidants (Dorman \& Hiltunen, 2004).

The antioxidant activity in vitro can be carried out by means of free radical trapping methods. Among these methods, it can be described the ferric reducing antioxidant power (FRAP), which reduces the capacity of the phenolic reagent of Folin-Ciocalteu, purifying effects in relation to 1,1-diphenyl-2-picrylhydrazyl (DPPH), and 2,2'-azino-bis(3ethylbenzothiazoline-6-sulfonic acid) (ABTS) (Prior \& Schaich, 2005; Brewer, 2011). They are based on the principle of transfer of a single electron and are low-cost and easily accessible, commonly applied in food technology (Pérez-Burillo et al., 2018; Santos et al., 2018).

$U$. tomentosa is a climbing vine native from the Amazon Forest and its active principles are di-vided into two groups: oxindole alkaloids and phenolic acids (Bors et al., 2011). The polyphenols have the ability to inhibit free radicals, specifically flavonoids, phenolic acids and tannins (Sand-oval et al., 2000). Also, they are used in food conservation, due to some bioactive properties that are beneficial to human health, making it possible for these molecules to replace some synthetic food additives (Caleja et al., 2016; Oak et al., 2005).

Citric acid, or 2-hydroxy-1,2,3-propanetricarboxylic acid, is a weak organic acid, commonly used as a natural preservative to increase the shelf life of products in the food industry (Abdel-Salam et al., 2018; Muñoz-Bernal et al., 2017). Studies have suggested that the use of citric acid can inhibit color change and oxidation effects on vegetable tissue, reducing losses in the appearance of products (Rocculi et al., 2007). Also, the combination of citric acid with other antioxidant components could delay the deterioration of some fruits like mango, inhibiting metabolic reactions by the presence of oxygen (Chiumarelli et al., 
2010). It has been previously demonstrated that the interaction of several antioxidants together demonstrated a more efficient synergistic behavior and better stability, regarding the oxidation activity than when antioxidants are applied individually (de Guzman et al., 2009, Tang et al., 2010; Tang et al., 2008; Marinova et al., 2008; Becker et al., 2007; Sharma et al., 2007; Erhan et al., 2006; Rawat et al., 2015).

In this scenario, this study aims to examine the content of phenolic compounds and antioxidant activity of bark and leaves extracts from $U$. tomentosa compounds with an addition of different concentrations of citric acid, in order to synergistically enhance the antioxidant activity. The study was performed by using fast, cheap and classical antioxidant methods, such as Folin-Ciocalteu reducing capacity, inhibition of the free radical of 2,2diphenyl-1-pricrylhydrazil (DPPH), ferric reducing antioxidant power (FRAP), and scavenging capacity of cationic free radicals of 2,2'-azino-bis (3-ethylbenzothiazoline-6sulfonic acid) (ABTS).

\section{MATERIALS AND METHODS}

\subsection{VEGETAL MATERIAL}

The leaves ( $L$ ) and barks (B) used were collected from Ucayali region, Peru. This material was washed with $5 \%$ sodium hypochlorite and ultrapure water, then stored, protected from light, and refrigerated at $3{ }^{\circ} \mathrm{C}$. For the extraction, samples were vortexed (Scientific Industries Inc., USA), centrifuged (BOECO, Germany) at 3,000 rpm for $30 \mathrm{~min}$, stored in an orbital shaker (BOECO, Germany) in constant agitation of $100 \mathrm{rpm}$, at room temperature, for $24 \mathrm{~h}$ subsequently. The extraction was carried out with a Soxhlet equipment, for $5 \mathrm{~h}$, in a proportion of 95:5 of water:ethanol $(\mathrm{v} / \mathrm{v})$ (Adaramola \& Onigbinde, 2017). All procedures were performed in the dark. To improve the antioxidant capacity, increasing concentrations of citric acid solutions $\left(0,5,10,15,20,30\right.$ and $\left.50 \mathrm{mg} \mathrm{mL}^{-1}\right)$ were used to promote the synergistic effect, and incubated for $24 \mathrm{~h}$.

\subsection{CHEMICAL REAGENTS}

Citric acid; phospho-molybdenum-tungstic acid (Folin-Ciocalteu reagent); sodium carbonate ( $\left.\mathrm{Na}_{2} \mathrm{CO}_{3}\right)$; gallic acid; 2,2-diphenyl-1-picrylhydrazyl (DPPH); 6-hydroxy-2,5,7,8- 
tetramethylchroman-2-carboxylic acid (Trolox); 2,4,6-tris(2-pyridyl)-s-triazine (TPTZ); ferric chloride (FeCl3); hydrochloric acid ( $\mathrm{HCl})$; sodium acetate; 2,2'-azino-bis(3ethylbenzothiazoline-6-sulfonic) acid (ABTS), and potassium persulfate $\left(\mathrm{K}_{2} \mathrm{~S}_{2} \mathrm{O}_{8}\right)$ were purchased from Sigma Aldrich Chemical Co. (St. Louis, MO). Ethanol (96\%) was purchased from Diproquim Productos Químicos (Arequipa, Peru).

\subsection{TOTAL POLYPHENOLS ASSAY}

According to Farahani et al. (2019), modified and adapted for this study, this method generates a change in coloration from yellow to a bluish shade, in which its intensity depends on phenol concentration in the sample (Fig. 1A). Therefore, by measuring the absorbance of the resulting product, the concentration can be determined based on a previous calibration curve of gallic acid. This preparation was performed adding $2 \mathrm{~mL}$ of a $2 \%$ solution of $\mathrm{Na}_{2} \mathrm{CO}_{3}(w / v), 200 \mu \mathrm{L}$ of the extract studied and $200 \mu \mathrm{L}$ of Folin-Ciocalteu reagent to test tubes, in darkness for $30 \mathrm{~min}$. The absorbance was read at $750 \mathrm{~nm}$ in a spectrophotometer (BOECO, Germany). The results were expressed in milligrams of gallic acid per gram of Uncaria tomentosa extract (EUt) (mg GAE/g EUt).

\subsection{ANTIOXIDANT ACTIVITY METHODS}

\subsubsection{DPPH radical scavenging capability}

For this essay (Fig. 1B), according to the method developed by Grimalt et al. (2018), adapted for this study, $3.9 \mathrm{~mL}$ of an ethanolic solution of DPPH ( $\left.25 \mathrm{mg} \mathrm{L}^{-1}\right)$ was taken with $100 \mu \mathrm{L}$ of sample, during $2 \mathrm{~h}$ in darkness, and analyzed in a spectrophotometer at a wavelength of $517 \mathrm{~nm}$. The percentage of inhibition of free radicals was calculated following the equation below:

$$
I \%=\left[\frac{A b s_{D P P H}-A b s_{\text {sample }}}{A b s_{D P P H}}\right] \quad(\text { Eq. } 1)
$$

where "AbSDPPH" is the absorbance of the DPPH stock solution, and "Abssample" is the absorbance value obtained from samples at the time of the reaction decay. Therefore, the results were expressed as percentage of radical inhibition. 


\subsubsection{Ferric Reducing Antioxidant Power (FRAP)}

The present protocol was adapted from Zaouali et al. (2010). Briefly, a $10 \mathrm{mmol} \mathrm{L}^{-1}$ solution of the reagent TPTZ was prepared, using $0.0312 \mathrm{~g}$ of TPTZ reagent into a $10 \mathrm{~mL}$ flask, which was filled with a solution of $40 \mathrm{mmol} \mathrm{L}^{-1}$ of hydrochloric acid. To obtain the complete FRAP solution, the resulting solutions were mixed in the following proportions: 2.5 $\mathrm{mL}$ of the ferric chloride solution ( $20 \mathrm{mmol} \mathrm{L}^{-1}$ ), $2.5 \mathrm{~mL}$ of the TPTZ solution, and $25 \mathrm{~mL}$ of the sodium acetate buffer. The reagent was kept in a thermostatic bath at $37^{\circ} \mathrm{C}$. For the reaction, $90 \mu \mathrm{L}$ of samples, $270 \mu \mathrm{L}$ of distilled water and $270 \mu \mathrm{L}$ of the complete FRAP solution were added. The absorbance of this reaction was measured at $595 \mathrm{~nm}$, with subsequent readings each $30 \mathrm{~min}$ (Fig. 1C).

\subsubsection{ABTS - Cationic Free Radical Scavenging Capacity}

This method is faster and more versatile to measuring the antioxidant activity of an extract, due to its high reproducibility rates. Also, the essay is effective to quantify both polar and non-polar compounds (Kuskoski et al., 2005). To generate the radical, a solution of ABTS at a concentration of $7 \mathrm{mmol} \mathrm{L}^{-1}$ was mixed with a solution of potassium persulfate at $2.45 \mathrm{mmol} \mathrm{L}^{-1}$. The mixture was incubated at room temperature in the dark for $16 \mathrm{~h}$. After, an equal volume of phosphate buffer was added, and the preparation was placed in a thermostatic bath at $30^{\circ} \mathrm{C}$. A volume of $2.97 \mu \mathrm{L}$ of this solution was collected and placed in test tubes. Subsequently, $30 \mu \mathrm{L}$ of the extracts were added. These samples were also diluted in ethanol to measure the absorbance at $734 \mathrm{~nm}$. The white reagent consisted of the solution of the stable radical ABTS $\bullet+$ dissolved in ethanol (Fig. 1D). The results were expressed in TEAC (Trolox equivalent antioxidant capacity) (mmol L-1 TEAC/g of EUt).

\subsection{STATISTICAL ANALYSIS}

The means were analyzed using ANAVA method in the InfoStat-Statistical Software 2018. In order to investigate the relationships between the study variables, the Pearson Correlation Analysis was adopted, which indicates a positive or negative existence between two variables, and $\alpha=5 \%$ (correlation coefficient) was adopted to verify the significance. The analysis were performed by Statistica and Sigmaplot software. The principal component multivariate analysis (PCA) was carried out to verify the group of different responses into 
three distinct of citric acid concentrations in $U$. tomentosa. The variables adopted were the biochemical parameters: polyphenols and antioxidant activity; biometric parameters: leave and bark of the sample (aerial part) and score plot. In this way, it was possible to simulate the relationship between these variables (Vítolo et al., 2012). For the analysis, the Statistica software was executed using the minimum absorption criterion of $80 \%$ in the first two main components and, thus, simulating a possible relationship between the variables (Cruz et al., 2004; Souza et al., 2018).

Figure 1 - Theoretical basis of the methods used in this work to evaluate the antioxidant profile: (a) FolinCiocalteu; (b) DPPH free radical scavenging; (c) Ferric Reducing Antioxidant Power; (d) ABTS cationic free radical scavenging.

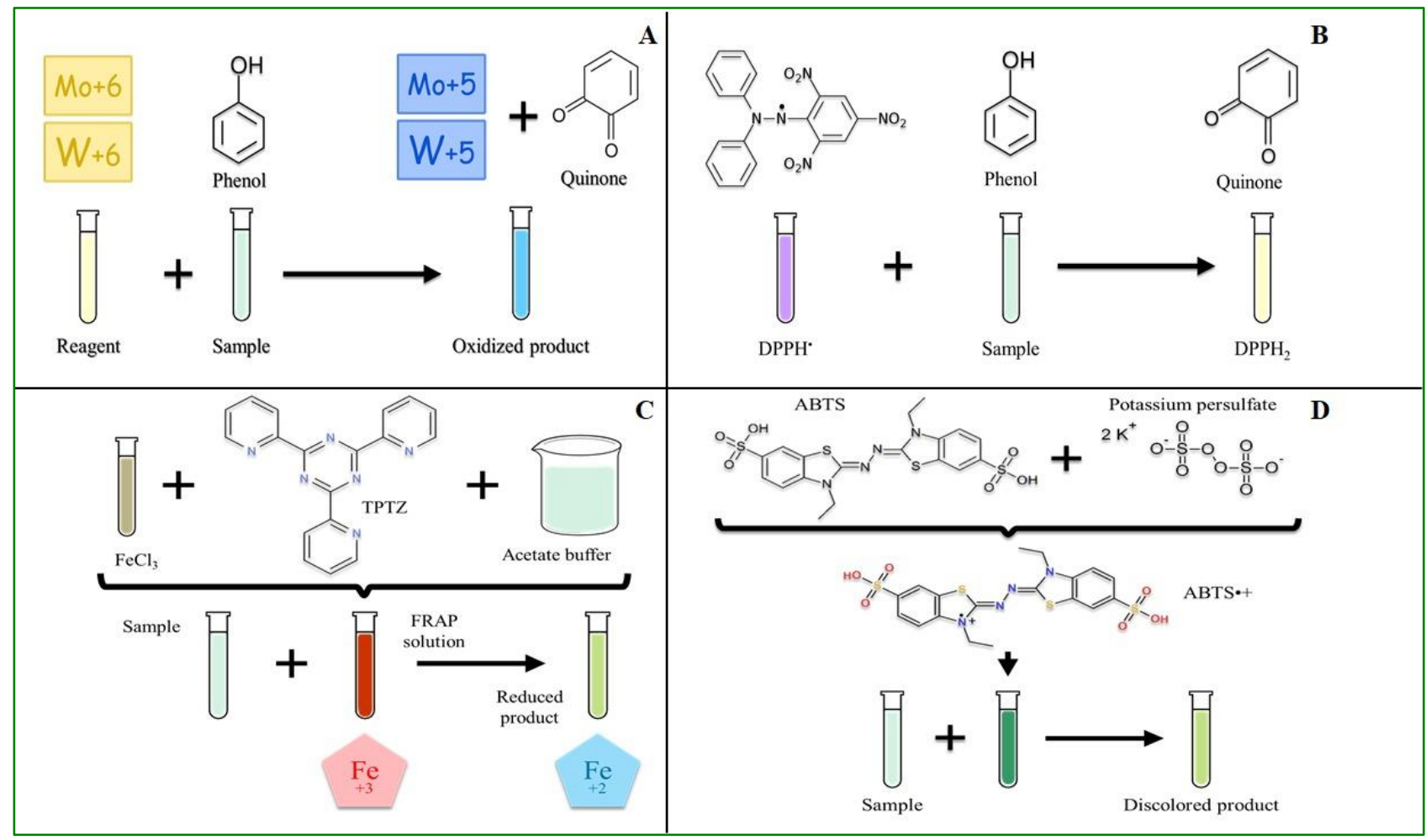

Source: the authors.

\section{RESULTS AND DISCUSSION}

\subsection{FOLIN-CIOCALTEU REDUCING CAPACITY}

The concentration of total polyphenols in EUt from leaves and barks varied significantly (Fig. 2), presenting, as initial values from the pure extracts, $449.1 \mathrm{mg} \mathrm{GAE} \mathrm{g}^{-1}$ EUt and $379.12 \mathrm{mg} \mathrm{GAE} \mathrm{g}^{-1}$ EUt, respectively. The total value of polyphenols observed in 
EUt did not show a significant difference when compared to the extracts incubated with citric acid of $5 \mathrm{mg} \mathrm{mL}^{-1}$. However, from $10 \mathrm{mg} \mathrm{mL}^{-1}$ of citric acid, the results for total polyphenol reduction capacity increased proportionally. In addition, it was observed an increasing linear relationship for total polyphenols concentration for both plant structures studies $(P<0.05)$. This effect was more pronounced on the leaves than the barks for higher concentrations (15 and $25 \mathrm{mg} \mathrm{mL}^{-1}$ ), in which there were significative differences between the values found in bark and leaf.

The Folin-Ciocalteu test is not specific only to phenolic compounds, since it reacts to sodium bisulfite, reducing sugars, tricarboxylic acids, some transition metals and aromatic amino acids (i.e. tryptophan and tyrosine), deviating the real value of the total polyphenol content in the sample (Granato et al., 2016; Chen et al., 2015). Besides that, it was found that a large variety of biomolecules present in the extracts can react to the mixture of tungsten and molybdenum (Molyneux, 2004). This overestimation is a product of the interaction between citric acid with the Folin-Ciocalteu reagent, since the REDOX reaction is similar to the one that occurs between acid and polyphenols. These defects in sensitivity can be corrected by means of three different ways: first, by subtracting the concentrations given by the pure extract with those obtained by each one of the components that are not phenolic; second, more selective polyphenol purification methods can be employed, and third, by treating the plant extract with an oxidizing agent such as hydrogen peroxide $(\mathrm{H} 2 \mathrm{O} 2)$ (Sánchez-Rangel et al., 2013).

Significant and positive correlations were exhibited between phenolic compounds and antioxidant activity, resulting from DPPH and FRAP methods. The antioxidant activity of plant-derived products is known to be influenced not only by their total polyphenol content, but also by the phenolic composition. In general, positive correlations are usually observed between evaluations of antioxidant activity and phenolic compounds (Tagliazucchi et al., 2010; Burin et al., 2014). 
Figure 2 - Total polyphenols of Uncaria tomentosa extracted from leaves (black circles) and barks (white circles), in function of different concentrations of citric acid.

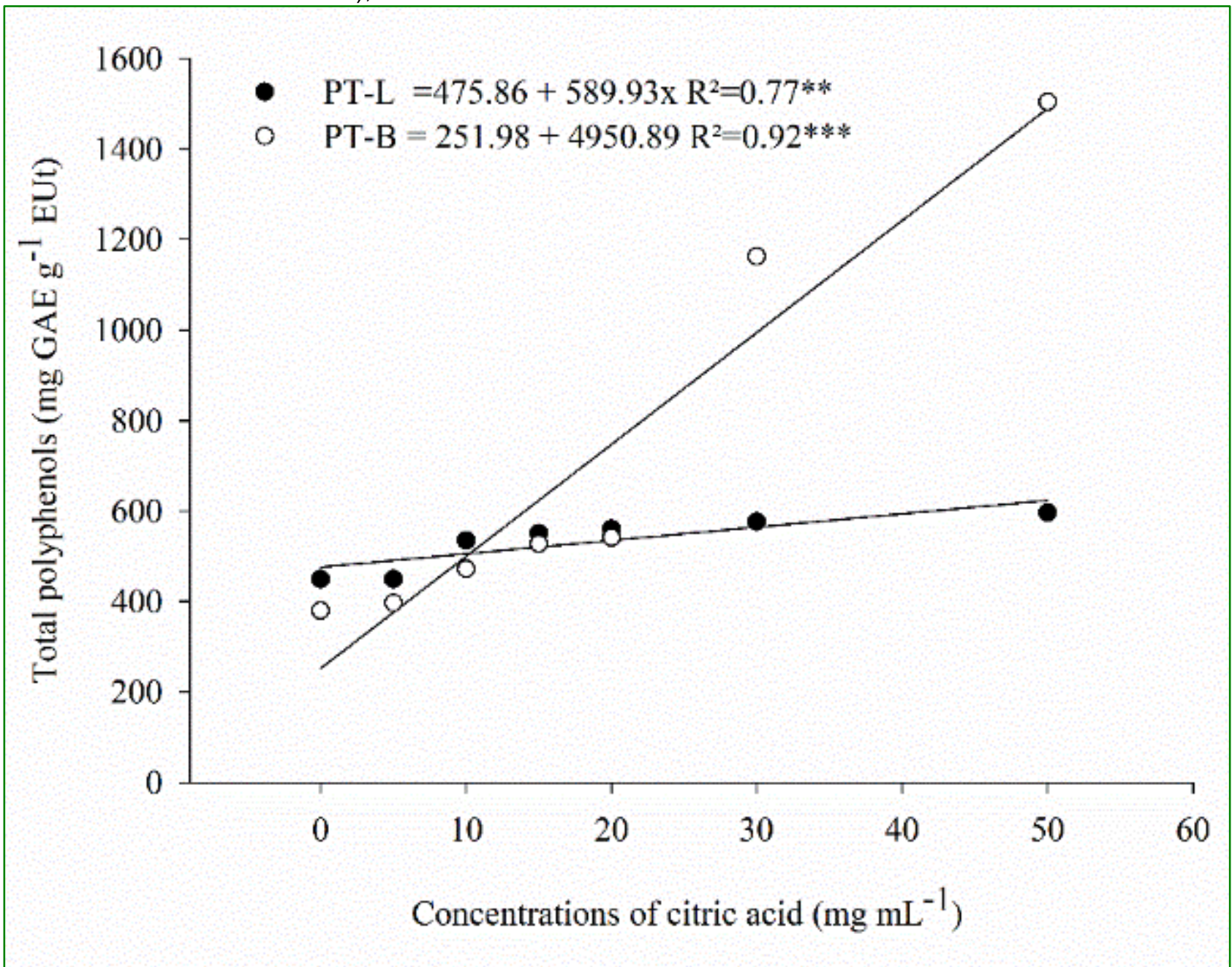

Source: the authors.

\subsection{MEASUREMENT OF ANTIOXIDANT CAPACITY}

\subsubsection{Free radical scavenging capacity}

In Fig. 3, it is observed a linear increasing of the free radical inhibition in function of the increment concentration of citric acid for both extractions by the DPPH method. For the leaf's extraction, a similar effect was observed when compared the Folin-Ciocalteu experiment (Fig. 2), with a more pronounced increasing of the free radical inhibition occurred in the bark structure. The antioxidant capacity demonstrated from leaves extracts of the $U$. tomentosa resulted in higher percentage of free radical inhibition, when comparing with the barks. It was also observed that the leaves do not have a significant synergistic effect with 
citric acid was added to this extract; on the other hand, the antioxidant activity of barks enriched with citric acid presented a notable raising at higher concentrations.

In ABTS experiments, the leaves and barks extracts without treatment presented an antioxidant activity of 1.34 and $1.14 \mathrm{mmol} \mathrm{L}^{-1} \mathrm{TEAC} / \mathrm{g}$ of EUt, respectively, showing that the polyphenols present in the bark extract of $U$. tomentosa are less effective on preventing oxidative damage than their analogues in the plant leaves (Fig. 4). However, when it interacts with citric acid, the antioxidant capacity increases synergistically and significantly in this extract. This activity exceeds three times the antioxidant capacity of the DPPH method and almost twice as much in the ABTS method.

Figure 3 - DPPH experiments performed in leaves (black circles) and barks (white circles) extracts from Uncaria tomentosa in function of the addition of different concentrations of citric acid.

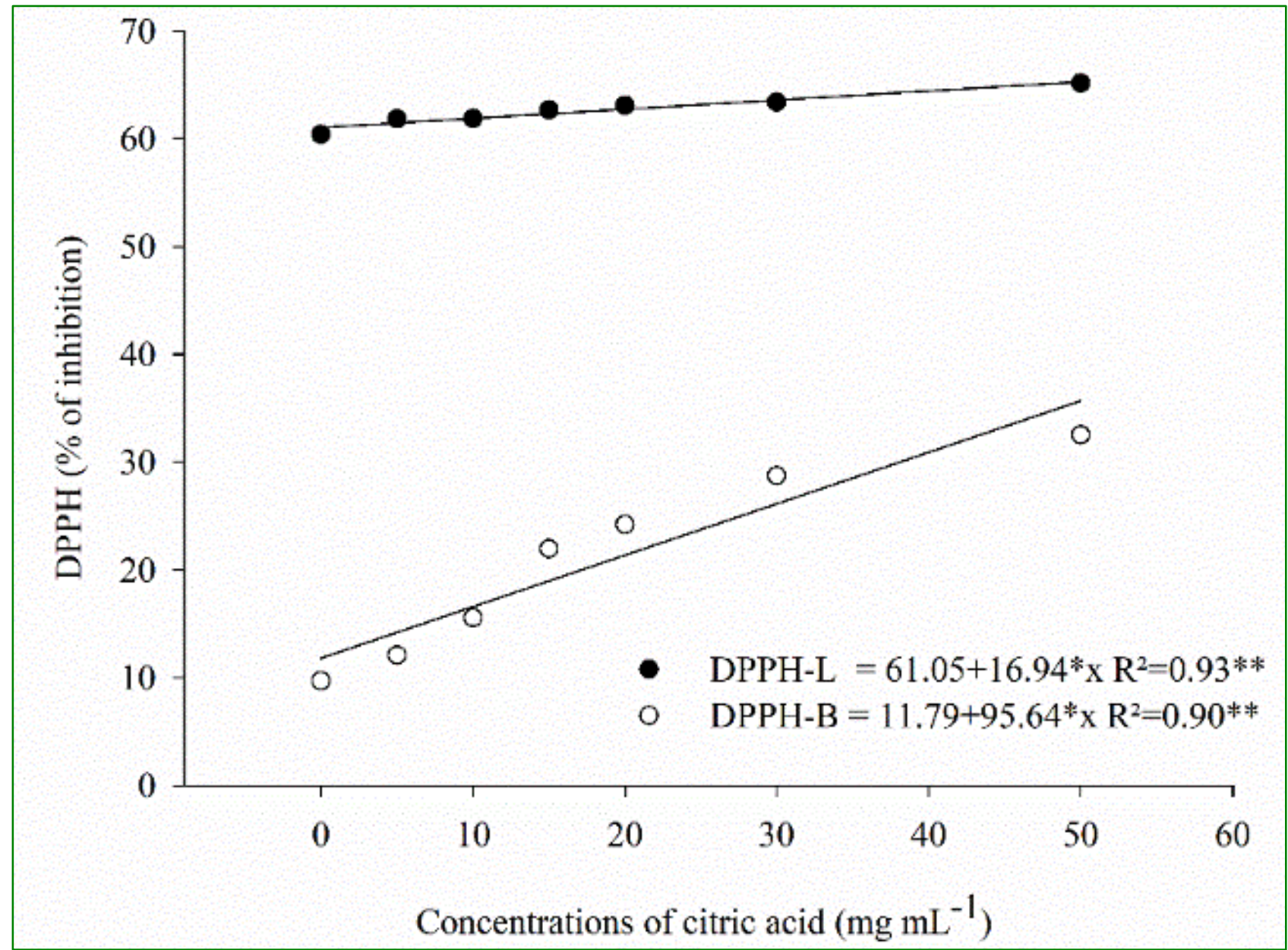

Source: the authors.

Previous studies have stated differences between antioxidant profiles of leaves, barks, and roots (Bors et al., 2011). However, according to Sandoval et al. (2002), the EUt have a high capacity to inhibit DPPH radicals, regardless of which part of the plant is used. 
The study evaluated lyophilized EUt of bark at different concentrations, and the results ranged from $3.5 \%$ for $1 \mathrm{\mu g} \mathrm{mL}^{-1}$ of extract, the minimal concentration used, to $85.5 \%$, when the mass extract was $100 \mu \mathrm{g}$ of freeze-dried bark for each $\mathrm{mL}$ of water. In comparison, the extracts prepared in the present study had a proportion of $5 \mu \mathrm{gL}^{-1}$ and inhibited $9.7 \%$ of the radicals. Results based on studies of commercial extracts of $U$. tomentosa indicate that this high antioxidant effect is due to the presence of proanthocyanidins, which can be found in the cortex (Navarro et al., 2019). Therefore, this pronounced increase in antioxidant activity could be linked to the interaction between proanthocyanidins and citric acid. It can be inferred that lyophilization and extraction by agitation are techniques of similar performance and give the extracts a very similar antioxidant profile. In overall, these results indicate that it is possible to use the antioxidants of $U$. tomentosa for different processes, where the use of citric acid is involved as, for example, in the use of natural preservatives, which can be optimized by lyophilization.

Figure 4 - ABTS essays from leaves (black circles) and barks (white circles) extracts from U. tomentosa in function of the addition of different concentrations of citric acid.

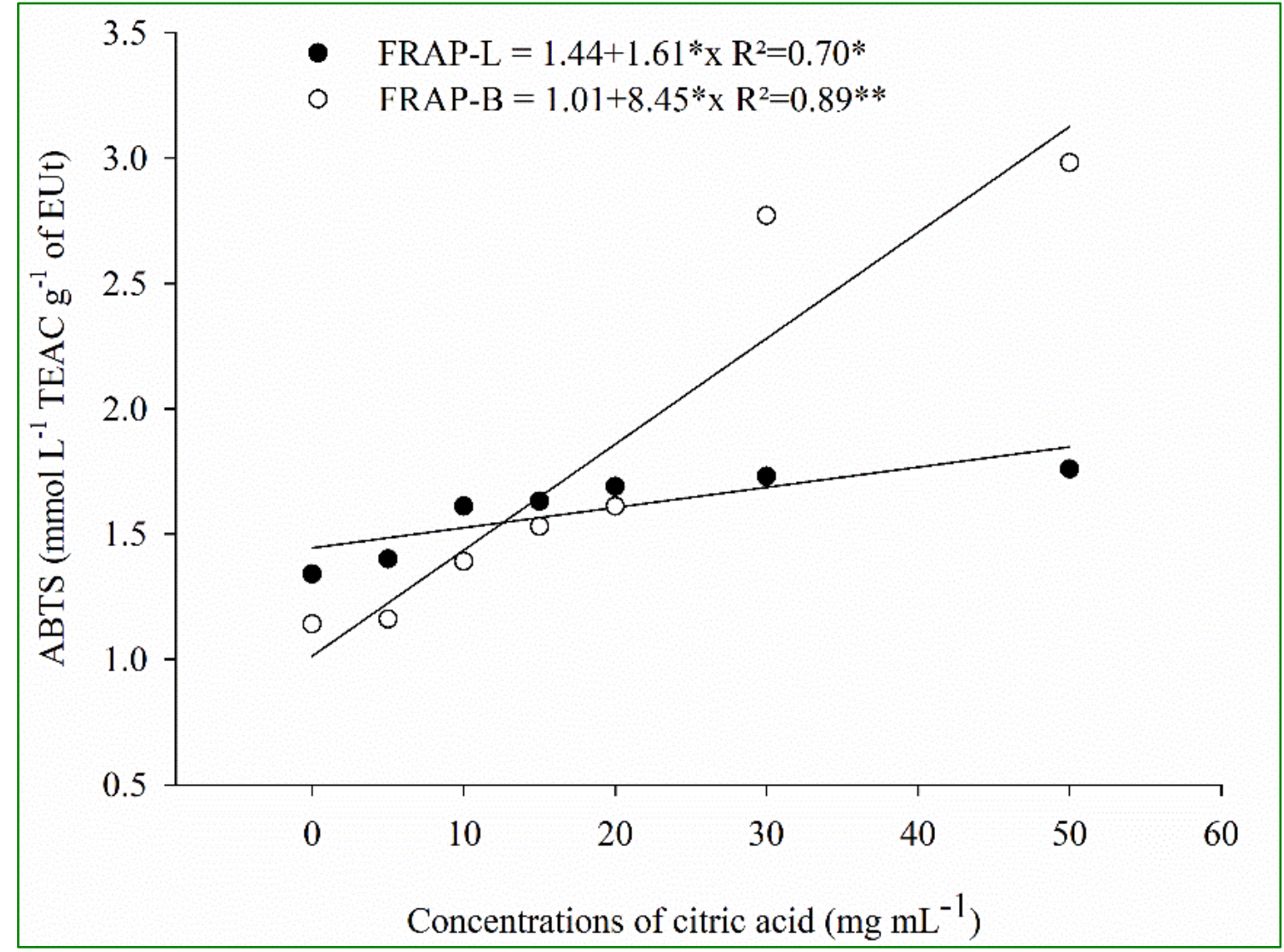

Source: the authors. 


\subsubsection{Ferric Reducing Antioxidant Power}

The results obtained show an inversely proportional curves for both samples analyzed, when the citric acid was added, as shown in the Fig. 5.

Figure 5 - FRAP studies from leaves (black circles) and barks (white circles) extracts from U. tomentosa in function of the addition of different concentrations of citric acid.

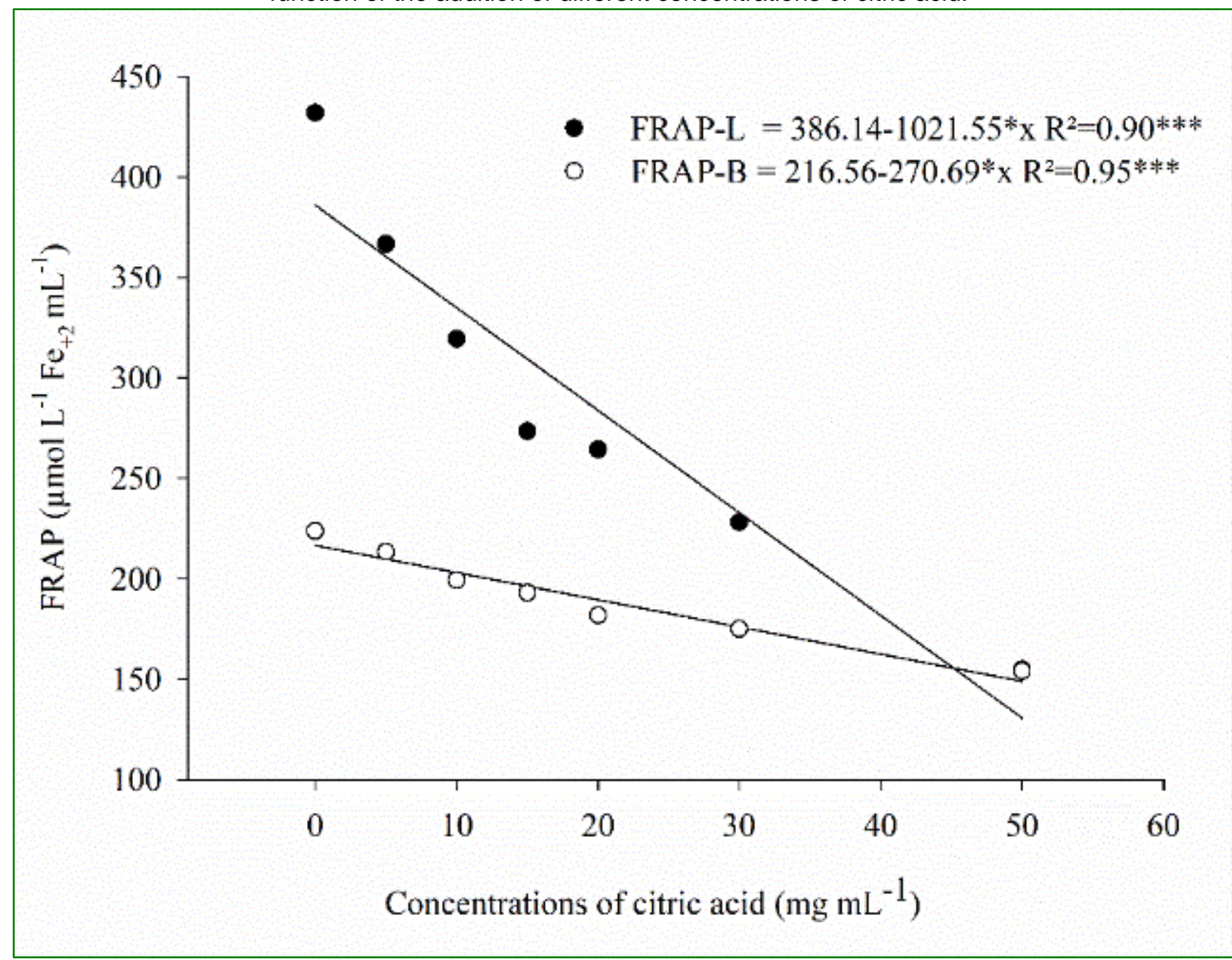

Source: the authors.

The decreasing of the antioxidant effect was notably on the leaves extracts and occurred in less intensity in the bark structure, as the citric acid concentration was arising. Citric acid has a high affinity to metal ions, especially for $\mathrm{Fe}^{+2}$ (Abdel-Salam et al., 2018). When applying the FRAP method, a citrus-treated plant extract was mixed with the Fe-TPTZ complex reducing the iron to $\mathrm{Fe}^{+2}$, which generated the blue color. However, this reaction is almost simultaneous, because when the reaction produces $\mathrm{Fe}^{+2}$ ions, the citric acid will be converted to ferrous citrate, which does not display absorbance at $595 \mathrm{~nm}$. The greater the amount of citric acid added to reaction, the more salt will be formed. Also, the ferrous citrate 
can be formed reacting with some metals present in the plant extract, a fact that explains the inversely proportional results, contrary to those expected. Even so, these can be an evidence that there is a greater increase in synergistic antioxidant activity in leaves than in barks extracts $(P<0.001)$. The reaction occurs normally in the absence of citric acid, fact that does not happen when it is added in different concentrations. Thus, citric acid traps the $\mathrm{Fe}^{+3}$ ions from the $\mathrm{Fe}$ (III)-TPTZ complex to form citrate salts and proportionally decreases the amount of Fe(II)-TPTZ complex formation (Fig. 6).

Figure 6 - Possible explanation mechanisms for the results obtained in the FRAP study. A. Explanation of the chemical reaction between the EUt sample (in the form of a free radical) and the TPTZ complex. B. Interaction between the EUt incubated and the TPTZ complex.

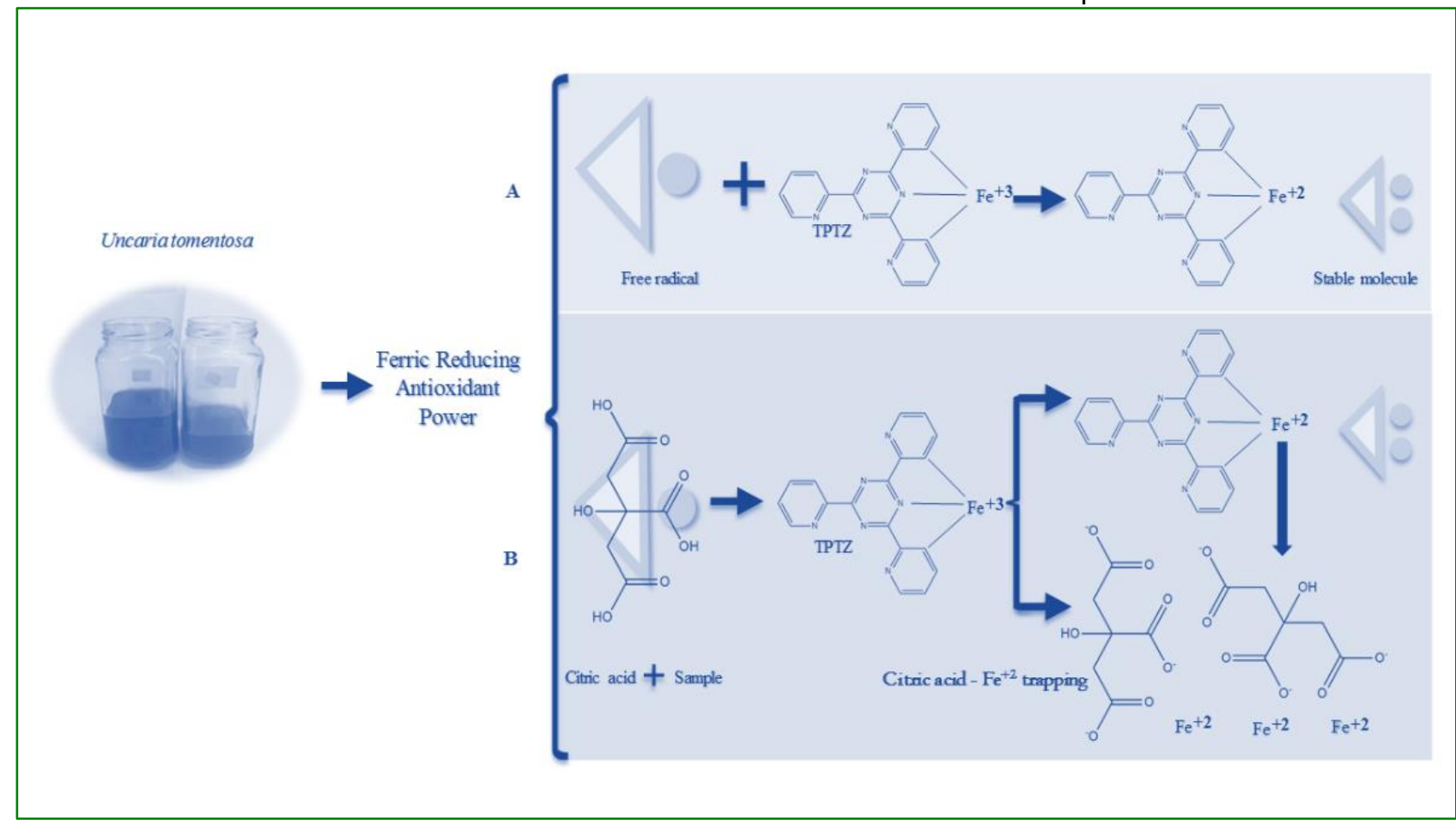

Source: the authors.

The multivariate analysis was performed to verify the grouping of the different responses and to obtain additional information about the influence of citric acid concentrations on the biochemical parameters involved with quality, in order to reduce $U$. tomentosa losses. Components F1 and F2 (citric acid concentrations and antioxidant activities, respectively) were found to account for $97.70 \%$ of the experiment variance (Fig. 7). However, it can be seen in quadrant (B) that there is a close approximation to the data obtained in the analysis of antioxidant activity by the FRAP method in both leaves and barks, which can be evidenced in the Table 1, which shows a reduction in antioxidant activities as 
the citric acid doses increased, contrary to the other observations. It can be verified that all other results showed similar behavior of increases previously evidenced in their contents and activities, as demonstrated in Fig. 7 , in quadrants $(A)$ and $(C)$.

Table 1 - Correlation analysis between the citric acid concentrations used and the biochemical responses in $U$. tomentosa bark and leaves extracts (Pearson method).

\begin{tabular}{lllllllll}
\hline Variable & TP-L & TP-B & DPPH-L & DPPH-B & FRAP-L & FRAP-B & ABTS-L & ABTS-B \\
\hline TP-L & 1 & & & & & & & \\
TP-B & 0.741 & 1 & & & & & & \\
DPPH-L & 0.868 & 0.870 & 1 & & & & & \\
DPPH-B & 0.938 & 0.875 & 0.952 & 1 & & & & \\
FRAP-L & -0.942 & -0.856 & -0.982 & -0.977 & 1 & & & \\
FRAP-B & -0.936 & -0.886 & -0.978 & -0.981 & 0.989 & 1 & & \\
ABTS-L & 0.992 & 0.725 & 0.878 & 0.935 & -0.947 & -0.938 & 1 & \\
ABTS-B & 0.798 & 0.985 & 0.869 & 0.914 & -0.879 & -0.904 & 0.789 & 1 \\
\hline
\end{tabular}

*Significant correlation values for $\alpha=5 \%$. Values in bold are different from 0 with a significance level $\alpha=5 \%$. Table caption: B (bark); L (leaves); - TP (Total Polyphenols); DPPH (antioxidant activity for DPPH method); ABTS (antioxidant activity for ABTS method) e FRAP (antioxidant activity for FRAP method).

Source: the authors.

A principal component analysis (PCA) was performed on the treatment dataset with increasing citric acid concentrations and biochemical parameters, to provide a better visualization of the effects of treatments in a reduced size. In PCA, it was sought to explain the total data variance and the correlations (or covariance) between variables. The main components are linear combinations of the original variables. In factor analysis (FA), the original variables are linear combinations of the factors. The attributes evaluated (eight original variables, TP - total polyphenols, DPPH, ABTS and FRAP in bark and leaves) were grouped into six factors, and the readjusted model was able to explain $99.99 \%$ of the variances with eigenvalues greater than 1 (Table 2). The first component explained $91.72 \%$ of the parameters studied in the increasing concentrations of citric acid.

The factor $F 1$, with explains $91,72 \%$ of the total variation, was effectively separated by the ap-plication of 0,10 , and $0.25 \mathrm{mg} \mathrm{mL}^{-1}$ of citric acid, whose variables were assessed in function of evaluations in leaves and barks (Fig. 7). Analyzing the F1 loadings, it suggests that there is a separation between DPPH-L, DPPH-B, TP-B, TP-L, ABST-B, ABTS-L, which presented negative loadings. For the factor $F 2$, which explains only $5,98 \%$ of the total variation and effectively distanced the citric acid doses applied of $0.1,0.075$ and $0.05 \mathrm{mg} . \mathrm{L}^{-}$ 1 from the others. The variables that received the greatest score were TP-B e ABTS-B and, 
according to the results, demonstrated high correlated values and thus affecting the respective doses. In addition, it is observed that FRAP-L e FRAP-B were not effective regarding the separation of the applied doses, because they presented similar behaviors. Finally, in Table 2, the correlated variables which explain the PCA factor F3, with positive values, showed only $1,78 \%$ of the total variance. Therefore, the analysis of main components was essential for the experiments interpretation and efficient to confirm and corroborate the correlation of the results obtained experimentally in the present study.

Figure 7 - Principal component analysis plot of citric acid concentrations used and their biochemical responses in $U$. tomentosa barks and leaves.

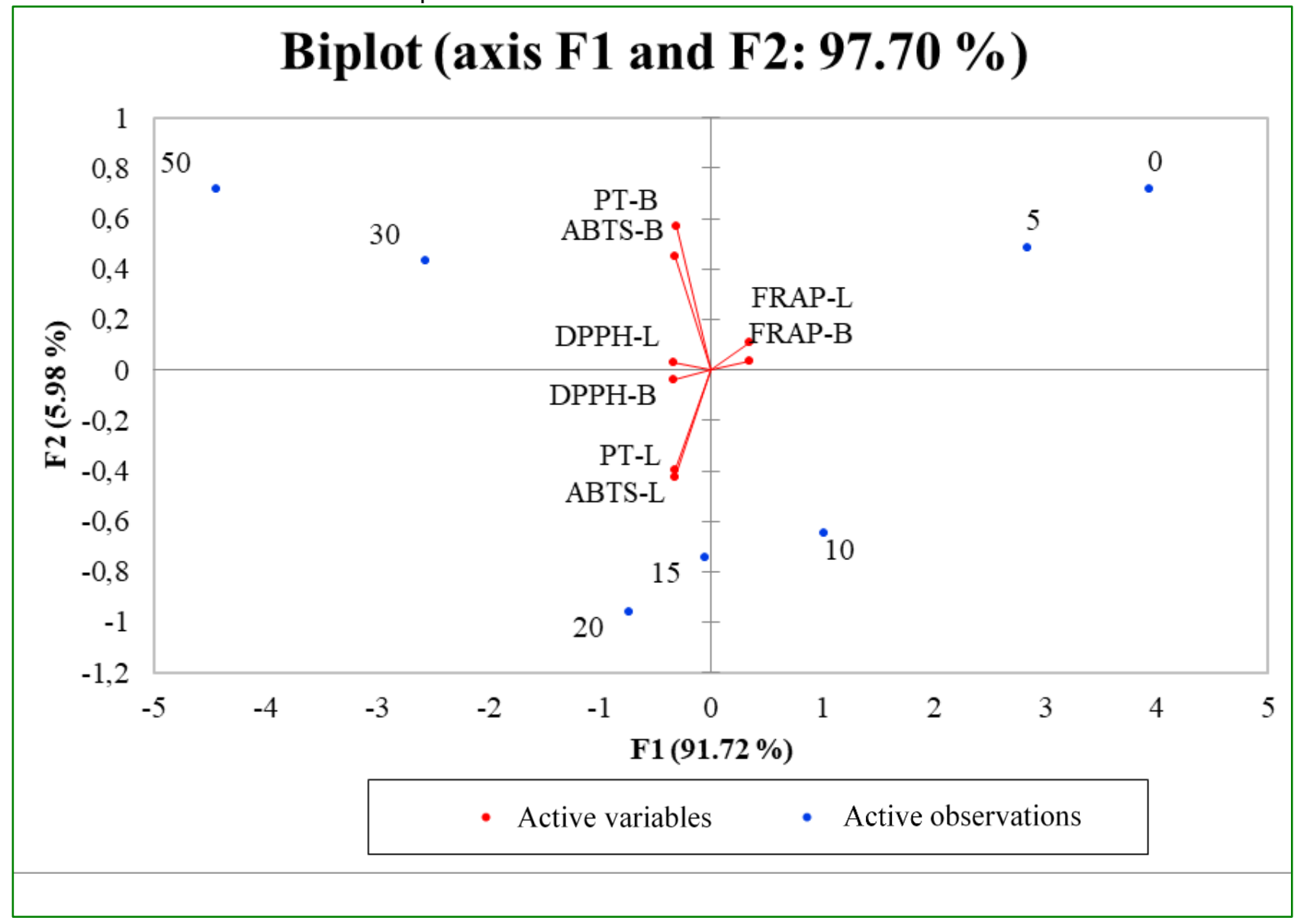

Source: the authors. 
Table 2 - Summary of auto-values, variability, and percent variability of six PCA principal com-ponents (PC) of eight original variables.

\begin{tabular}{lllllll}
\hline Variable & F1 & F2 & F3 & F4 & F5 & F6 \\
\hline TP-L & -0.348 & -0.423 & -0.392 & -0.198 & -0.438 & 0.396 \\
TP-B & -0.334 & 0.606 & -0.136 & -0.349 & -0.245 & 0.162 \\
DPPH-L & -0.357 & 0.028 & 0.692 & -0.074 & 0.106 & -0.002 \\
DPPH-B & -0.365 & -0.040 & -0.014 & 0.867 & -0.186 & 0.061 \\
FRAP-L & 0.365 & 0.118 & -0.282 & 0.107 & -0.337 & -0.517 \\
FRAP-B & 0.367 & 0.040 & -0.189 & 0.141 & 0.445 & 0.627 \\
ABTS-L & -0.348 & -0.453 & -0.279 & -0.177 & 0.480 & -0.371 \\
ABTS-B & -0.344 & 0.479 & -0.395 & 0.138 & 0.401 & -0.125 \\
\hline & F1 & F2 & F3 & F4 & F5 & F6 \\
\hline Auto-value & 7.338 & 0.478 & 0.137 & 0.027 & 0.011 & 0.008 \\
\hline Variability (\%) & 91.724 & 5.978 & 1.708 & 0.343 & 0.143 & 0.104 \\
\hline \% accumulated & 91.724 & 97.702 & 99.410 & 99.753 & 99.896 & 100.000 \\
\hline
\end{tabular}

Table caption: B (bark); L (leaves); - TP (Total Polyphenols); DPPH (antioxidant activity for DPPH method); ABTS (antioxidant activity for ABTS method) and FRAP (antioxidant activity for FRAP method).

Source: the authors.

\section{CONCLUSIONS}

Uncaria tomentosa showed a great antioxidant capacity through the results of free radical sweeping tests, DPPH and ABTS, confirming the hypothesis that it has a higher antioxidant capacity in the leaves, when compared to the barks. However, the synergistic effect with the addition of citric acid is more efficient in the bark than in the leaves, indicating remarkably high values of antioxidant activity enhancements. In the FRAP method, the assays showed that there was an increase in antioxidant capacity, which can be correlated to formation of citrate salts, which leads to an inversely proportional results. Statistical analysis confirmed the results of the addition of citric acid in the extracts of $U$. tomentosa improved their antioxidant capacity, showed approximately similar behavior of increases. In conclusion and to the best of our knowledge, the present study shows a very fast, low cost and straightforward evaluation for the use of $U$. tomentosa extracts combined with citric acid for enhancement of antioxidant activity for employment in the food industry. Therefore, this paper can contribute effectively to the obtaining of new combined natural additives and preservatives that help reduce monetary losses, incrementing the development of the agrofood industry. 


\section{REFERÊNCIAS}

ABDEL-SALAM, Omar ME, et al. Citric Acid an Antioxidant in Liver. En The Liver. Academic Press, 2018. p. 183-198. doi:10.1016/b978-0-12-803951-9.00016-1

ADARAMOLA, Banji; ONIGBINDE, Adebayo. Influence of extraction technique on the mineral content and antioxidant capacity of edible oil extracted from ginger rhizome. Chem Int, 2017, vol. 3, no 1, p. 1-7.

ANTOLOVICH, Michael, et al. Methods for testing antioxidant activity. Analyst, 2002, vol. 127, no 1, p. 183-198.

BECKER, Eleonora Miquel; NTOUMA, Georgia; SKIBSTED, Leif H. Synergism and antagonism between quercetin and other chain-breaking antioxidants in lipid systems of increasing structural organisation. Food Chemistry, 2007, vol. 103, no 4, p. 1288-1296.

BORS, Milena, et al. Protective activity of the Uncaria tomentosa extracts on human erythrocytes in oxidative stress induced by 2, 4-dichlorophenol (2, 4-DCP) and catechol. Food and chemical toxicology, 2011, vol. 49, no 9, p. 2202-2211.

BREWER, M. S. Natural antioxidants: sources, compounds, mechanisms of action, and potential applications. Comprehensive reviews in food science and food safety, 2011, vol. 10, no 4, p. 221-247.

BURIN, Vívian Maria, et al. Bioactive compounds and antioxidant activity of Vitis vinifera and Vitis labrusca grapes: evaluation of different extraction methods. Microchemical Journal, 2014, vol. 114, p. 155-163.

CALEJA, Cristina, et al. Fortification of yogurts with different antioxidant preservatives: A comparative study between natural and synthetic additives. Food chemistry, 2016, vol. 210, p. 262-268.

CHEN, Liang-Yu; CHENG, Chien-Wei; LIANG, Ji-Yuan. Effect of esterification condensation on the Folin-Ciocalteu method for the quantitative measurement of total phenols. Food chemistry, 2015, vol. 170, p. 10-15.

CHIUMARELLI, Marcela, et al. Cassava starch coating and citric acid to preserve quality parameters of fresh-cut "Tommy Atkins" mango. Journal of food science, 2010, vol. 75, no 5, p. E297-E304.

CRUZ, C. D.; REGAZZI, A. J.; CARNEIRO, P. C. S. Modelos biométricos aplicados ao melhoramento genético (volume 1. Viçosa, Editora UFV, 2004, vol. 1, p. 480p.

DE GUZMAN, Rhet, et al. Synergistic effects of antioxidants on the oxidative stability of soybean oil-and poultry fat-based biodiesel. Journal of the American Oil Chemists' Society, 2009, vol. 86, no 5, p. 459. 
DORMAN, H. J. D.; HILTUNEN, Raimo. Fe (III) reductive and free radical-scavenging properties of summer savory (Satureja hortensis L.) extract and subfractions. Food chemistry, 2004, vol. 88, no 2, p. 193-199.

ERHAN, Sevim Z.; SHARMA, Brajendra K.; PEREZ, Joseph M. Oxidation and low temperature stability of vegetable oil-based lubricants. Industrial Crops and Products, 2006, vol. 24, no 3, p. 292-299.

FARAHANI, Maryam, et al. Chemical characterization and antioxidant activities of Morus alba var. nigra fruits. Scientia Horticulturae, 2019, vol. 253, p. 120-127.

GRIMALT, M., et al. Physicochemical composition and antioxidant activity of three Spanish caper (Capparis spinosa L.) fruit cultivars in three stages of development. Scientia Horticulturae, 2018, vol. 240, p. 509-515.

GRANATO, Daniel, et al. Chemical perspective and criticism on selected analytical methods used to estimate the total content of phenolic compounds in food matrices. TrAC Trends in Analytical Chemistry, 2016, vol. 80, p. 266-279.

KUSKOSKI, E. M., et al. Application of several chemical methods to determine antioxidant activity in fruit pulps. Ciencia y Tecnología de Alimentos, Campinas, 2005, vol. 25, no 4, p. 726-732.

MARINOVA, E.; TONEVA, A.; YANISHLIEVA, N. J. F. C. Synergistic antioxidant effect of a-tocopherol and myricetin on the autoxidation of triacylglycerols of sunflower oil. Food chemistry, 2008, vol. 106, no 2, p. 628-633.

MOLYNEUX, Philip, et al. The use of the stable free radical diphenylpicrylhydrazyl (DPPH) for estimating antioxidant activity. Songklanakarin J. sci. technol, 2004, vol. 26, no 2, p. 211-219.

MUÑOZ-BERNAL, Óscar A., et al. New approach to the interaction between FolinCiocalteu reactive and sugars during the quantification of total phenols. TIP Revista Especializada en Ciencias Químico-Biológicas, 2017, vol. 20, no 2, p. 23-28.

NAVARRO, Mirtha, et al. Polyphenolic composition and antioxidant activity of Uncaria tomentosa commercial bark products. Antioxidants, 2019, vol. 8, no 9, p. 339.

OAK, Min-Ho; EL BEDOUI, Jasser; SCHINI-KERTH, Valérie B. Antiangiogenic properties of natural polyphenols from red wine and green tea. The Journal of nutritional biochemistry, 2005, vol. 16, no 1, p. 1-8.

PÉREZ-BURILLO, S., et al. Relationship between composition and bioactivity of persimmon and kiwifruit. Food Research International, 2018, vol. 105, p. 461-472.

PRIORRL, WuX. SchaichK, Standardized methods for the determination of antioxidant capacity and phenolics in foods and dietary supplements. J Agric Food Chem, 2005, vol. 53 , p. 4290-4302. 
RAWAT, Devendra S., et al. The effect of binary antioxidant proportions on antioxidant synergy and oxidation stability of Jatropha and Karanja biodiesels. Energy, 2015, vol. 84, p. $643-655$.

ROCCULI, Pietro, et al. Effects of the application of anti-browning substances on the metabolic activity and sugar composition of fresh-cut potatoes. Postharvest Biology and Technology, 2007, vol. 43, no 1, p. 151-157.

SÁNCHEZ-RANGEL, Juan Carlos, et al. The Folin-Ciocalteu assay revisited: improvement of its specificity for total phenolic content determination. Analytical Methods, 2013, vol. 5, no 21, p. 5990-5999.

SANDOVAL, Manuel, et al. Cat's claw inhibits TNFa production and scavenges free radicals: role in cytoprotection. Free Radical Biology and Medicine, 2000, vol. 29, no 1, p. 71-78.

SANDOVAL, M., et al. FM, Angeles, 685 RA Musah, P. Bobrowski, MJ Miller, Antiinflammatory and antioxidant activities of 686 cat's claw (Uncaria tomentosa and Uncaria guianensis) are independent of their 687 alkaloid content. Phytomedicine, 2002, vol. 9, p. 325-337.

SANTOS, Monique Barreto; DA COSTA, Naiara Rocha; GARCIA-ROJAS, Edwin Elard. Interpolymeric complexes formed between whey proteins and biopolymers: Delivery systems of bioactive ingredients. Comprehensive Reviews in Food Science and Food Safety, 2018, vol. 17, no 3, p. 792-805.

SHARMA, B. K.; PEREZ, J. M. k Erhan, SZ 20076 Soybean oil-based lubricants: a search for synergistic antioxidants. Energy Fuels, vol. 21, p. 2408-2414.

DE SOUZA, Angela Vacaro; DA SILVA VIEIRA, Marcos Ribeiro; PUTTI, Fernando Ferrari. Correlations between the phenolic compounds and antioxidant activity in the skin and pulp of table grape varieties. Brazilian Journal of Food Technology, 2018.

SUJA, Kizhiyedathu Polachira; JAYALEKSHMY, Anathasankaran; ARUMUGHAN, Chami. Free radical scavenging behavior of antioxidant compounds of sesame (Sesamum indicum L.) in DPPH • system. Journal of agricultural and food chemistry, 2004, vol. 52, no 4, p. 912-915.

TAGLIAZUCCHI, Davide, et al. In vitro bio-accessibility and antioxidant activity of grape polyphenols. Food Chemistry, 2010, vol. 120, no 2, p. 599-606.

TANG, Haiying, et al. Effect of antioxidants on the storage stability of soybean-oil-based biodiesel. Energy \& fuels, 2010, vol. 24, no 3, p. 2028-2033.

TANG, L., et al. 2008. Interactions among Ytm1, Erb1 and Nop7 required for assembly of the Nop7-subcomplex in yeast pre-ribosomes. Mol Biol Cell, vol. 19, p. 2844-2856. 
VÍTOLO, Hilton F.; SOUZA, Gustavo M.; SILVEIRA, Joaquim AG. Cross-scale multivariate analysis of physiological responses to high temperature in two tropical crops with $\mathrm{C} 3$ and C4 metabolism. Environmental and Experimental Botany, 2012, vol. 80, p. 54-62.

ZAOUALI, Yosr; BOUZAINE, Taroub; BOUSSAID, Mohamed. Essential oils composition in two Rosmarinus officinalis L. varieties and incidence for antimicrobial and antioxidant activities. Food and chemical toxicology, 2010, vol. 48, no 11, p. 3144-3152. 


\section{RESUMO}

Uncaria tomentosa, uma trepadeira notável por conter altas concentrações de alcaloides oxindois e compostos fenólicos, é comumente usada na medicina tradicional como agente anti-inflamatório e antioxidante. Além disso, o ácido cítrico é um aditivo alimentar amplamente utilizado como conservante, devido ao seu baixo custo. Dessa forma, este estudo tem como objetivo avaliar o conteúdo de compostos fenólicos de Uncaria tomentosa e avaliar sua atividade antioxidante quando o ácido cítrico, em diferentes concentrações, é adicionado ao extrato. Para isso, foi estabelecido um gradiente de concentrações de ácido cítrico, e o perfil antioxidante de extratos aquosos das folhas e cascas das plantas foram analisados pelo ensaio de Folin-Ciocalteu; inibição do radical livre de 2,2-difenil-1-picrilhidrazil (DPPH); poder antioxidante redutor férrico (FRAP) e capacidade de eliminação de radicais livres catiônicos do ácido 2,2'-azino-bis (ácido 3-etilbenzotiazolina-6-sulfônico) (ABTS). Os resultados mostraram um efeito sinérgico entre o ácido cítrico e os compostos antioxidantes de Uncaria tomentosa, apresentando significância estatística, no qual a o efeito sinérgico foi mais eficiente na casca do que nas folhas.

Palavras-chave: ABTS. DPPH. Folin-Ciocalteu. FRAP. Efeito sinérgico.

\section{RESUMEN}

Uncaria tomentosa, una trepadera notable por contener altas concentraciones de alcaloides oxindoles y compuestos fenólicos, es comúnmente utilizada en la medicina tradicional como agente anti-inflamatorio y antioxidante. Adicionalmente, el ácido cítrico es un aditivo alimentar ampliamente utilizado como conservante, debido a su bajo costo. De esta forma, este estudio tiene como objetivo evaluar el contenido de compuestos fenólicos de Uncaria tomentosa y evaluar su actividad antioxidante cuando el ácido cítrico, en diferentes concentraciones, es adicionado al extracto. Para esto, se estableció un gradiente de concentraciones de ácido cítrico, y el perfil antioxidante de extractos acuosos de las hojas y cáscaras de las plantas fueron analizados por el ensayo de Folin-Ciocalteu; inhibición del radical libre de 2,2-difenil-1-picril-hidrazil (DPPH); poder antioxidante reductor férrico (FRAP) y capacidad de eliminación de radicales libres catiónicos del ácido 2,2'-azino-bis (ácido 3etilbenzotiazolina-6-sulfónico) (ABTS). Los resultados mostraron un efecto sinérgico entre el ácido cítrico y los compuestos antioxidantes de Uncaria tomentosa, presentando significancia estadística, siendo que el efecto sinérgico fue más eficiente en la cáscara que en las hojas.

Palabras clave: ABTS. DPPH. Folin-Ciocalteu. FRAP. Efecto sinérgico. 


\section{LICENÇA DE USO}

Este é um artigo publicado em acesso aberto (Open Access) sob a licença Creative Commons Atribuição 4.0 Internacional (CC BY 4.0), que permite uso, distribuição e reprodução em qualquer meio, desde que o trabalho original seja corretamente citado. Mais informações em: http://creativecommons.org/licenses/by/4.0

\section{CONFLITO DE INTERESSES}

Os autores declaram que não há conflito de interesses neste trabalho.

\section{CONTRIBUIÇÕES AUTORAIS}

Cesar Augusto Roque Borda: Responsável da redação e validação de dados experimentais, obtenção dos recursos.

Camila Katerine Aranda Medina: Responsável de obtenção de dados preliminares e desenho das figuras.

Raiza Felismino Silveira: Responsável da tradução e discussão dos resultados.

Priscilla Ayleen Bustos Mac-Lean: Responsável da tradução e correções preliminares.

Angela Vacaro de Souza: Responsável das análises e interpretações estatísticas.

Fernando Ferrari Putti: Responsável das análises e interpretações estatísticas.

Eduardo Festozo Vicente: Responsável das correções e versão final.

\section{FINANCIAMENTO}

O presente trabalho foi realizado com apoio dos Fondos Concursáveis "Fomento e Incentivo a la Formación de los Semilleros 2017" Financiado pelo "Vicerrectorado de Investigación" da Universidad Católica de Santa María, e a Fundação de Amparo à Pesquisa do Estado de São Paulo (FAPESP) pela concessão de bolsa de mestrado processo n 18/25707-3.

\section{COMO REFERENCIAR}

ROQUE BORDA, Cesar Augusto; ARANDA MEDINA, Camila Katerine; SILVEIRA, Raiza Felismino; MAC-LEAN, Priscilla Ayleen Bustos; de SOUZA, Angela Vacaro; PUTTI, Fernando Ferrari; VICENTE, Eduardo Festozo. Comparative activity of total polyphenols and antioxidant compounds from uncaria tomentosa enhanced with citric acid. Revista Brasileira de Engenharia de Biossistemas (Tupã), v. 15, n. 1, p. 69-89, 2021. DOI: http://dx.doi.org/10.18011/bioeng2021v15n1p69-89.

\section{RESPONSABILIBADE EDITORIAL}

Prof. Dr. Fernando Ferrari Putti ${ }^{1}$, Prof. Dr. Paulo Sérgio Barbosa dos Santos ${ }^{1}$, Prof. Dr. Eduardo Festozo Vicente ${ }^{1}$ e Prof. Dr. Diogo de Lucca Sartori ${ }^{1}$

1 Universidade Estadual Paulista "Júlio de Mesquita Filho", FCE - Faculdade de Ciências e Engenharia, Tupã, SP, Brasil. 